\title{
I NEVER METATHEORY I DIDN'T LIKE
}

\section{George Ritzer \\ University of Maryland}

Mid-American Review of Sociology, 1991, Vol. XV, No. 2:21-32

The invitation to write autobiographically for the Centennial Celebration of the Department of Sociology at the University of Kansas arrived at an opportune moment for me. First, I was in the midst of book in which I was writing about the role of biography and autobiography in metatheoretical work in sociology (Ritzer 1991a). Second, I had just finished a review essay in which I analyzed three recent biographical and autobiographical works from that point of view (Ritzer 1991b). Third, I'd been reading a hot new autobiographical expose on drugs, booze, sex, and glitz in Hollywood, You'll Never Eat Lunch in This Town Again by Julia Phillips (1991), that had startling similarities to my experiences at Kansas in the early 1970s. It is the fact that biographical work is of intellectual and personal concern that I am able to overcome the natural embarrassment about writing autobiographically and to deal with my "Kansas years."

My basic premise is that biographical and autobiographical work is useful in helping us understand the work of sociological theorists, and of sociologists generally. In focusing on myself in this light, you, the reader, will need to grant me three things, things which are admittedly not easy to grant. First, you must concede that I am a sociologist. While I have taught in sociology departments for over twenty years, and have written a great deal about and in sociology, the fact is that $I$ have no degrees in sociology. My Bachelor's degree (City College of New York) is in psychology, my MBA (University of Michigan, and my Ph.D. (Cornell University) in industrial and labor relations obviously do not make me a credentialed sociologist. (Of course, and to show you the size of my ego, neither were Karl Marx and Max Weber.) So, you will need to overlook my lack of training in sociology in order to concede me the status of sociologist. In fact, one recollection from my first year on the job market continues to haunt me. Bucknell University dismissed my candidacy by telling me that I didn't qualify because they were interested in hiring a sociologist.)

Second, you will need to permit me to think of myself as a sociological theorist. One of my problems here is that since I was not trained in sociology, I could not have been trained in sociological theory. Most of what I have learned about sociological theory, I have learned, sort of like a blacksmith, on the job. One of my great pieces of luck here was that while I was hired as a sociologist by Tulane University in 1968, primarily to teach the sociology of work (one of the few things for which I was trained), it happened that Tulane also needed someone to teach its theory courses and they accepted my expression of interest as sufficient to allow me to teach the courses. I literally began to learn sociological theory while teaching it to undergraduates and graduates at Tulane University. To this day, I occasionally shudder over the misinformation I passed on to those students. Some of them are probably 
still wandering through life with such misconceptions as Marx was an economic determinist and Weber did little more than debate Marx's ghost. I can only guess at the ways in which their lives nave been deformed by these misconceptions.

Even today, many theorists do not think of me (assuming they think of me at all) as a compatriot. On the rare occasions that I enter their consciousness, it is as a metatheorist rather than as a theorist. While I have a good deal of theoretical work, especially the application of Weberian theory to various social phenomena, the fact is that the vast bulk of my work in this area has been metatheoretical. There is a very good reason for that. I have never truly understood sociological theory! Thus, I have devoted a good portion of my academic life to studying theory in order to better understand it. Luckily for me, I have found-editors who have been willing to publish my attempts at greater understanding in article and book form. The result is that I have been able to increase my understanding of theory with the same material that also allowed me to move up the academic career ladder and to earn some royalties along the way. Only in America! Only in American sociology!

Third, you will need to allow me the illusion that I have both produced a body of, largely meta-, theoretical work and that that work is worth reflecting upon. Clearly this, especially the latter part, is the most difficult to accept. How can someone not trained in sociology in general, and sociological theory in particular, have produced a body of theoretical work worthy of metatheoretical analysis? More, how could it possibly be worth sitting there and reading such autobiographical ruminations? Tough questions, but to go on (and it would be hard to stop me now) I have to assume that you will allow me to proceed as if there is a body of work worthy of analysis. My thesis, again, is that autobiography can be an aid in understanding a body of sociological theory. If I can convince you of the utility of this approach with this case study, then maybe we will be in the position to use it on the body of work of a real sociological theorist.

I will begin by considering the general place of biography in metatheoretical work. The historian of science, Thomas Hankins $(1979$, p. 14), says the following about the importance of the biography:

[a] fully integrated biography of a scientist which includes not only his personality, but also his scientific work and the intellectual and social context of his times, [is]...still the best way to get at many of the problems that beset the writing of history of science...science is created by individuals, and however much it may be driven by forces outside, these forces work through the scientist himself. Biography is the literary lens through which we can best view this process.

What Hankins asserts about scientists generally informs my orientation to the biographies of sociological theorists. It should be noted that the importance given to biography stands in opposition to the structuralist and post-struc- turalist perspectives that downplay the significance of the author and seek to analyze texts structurally.

Biography is directly related to one of the three basic metatheoretical approaches (Ritzer 1991a), metatheorizing as a means of attaining a greater understanding of sociological theory (MU) (the others are metathcorizing as a prelude to theory development and as a method for producing overarching theoretical perspectives). There are four basic ways of gaining such an understanding which are derived from the juxtaposition of the internal-external (to sociology) and social-intellectual continua (Ritzer 1988). The result is four domains in which one can enhance one's understanding of sociological theory: internal-social, internal-intellectual, external-social, and external-intellectual.

Biography can play two different roles here. First, it would be of concern in any metatheoretical analysis as one internal-intellectual and internal-social factor helping to shape a given theory. Second, and more important from the point of view of this undertaking, it can serve as a lens to look at all four of the domains of MU. Each of those areas can be looked at from an autobiographical (or biographical) point of view. I will follow the second approach in the ensuing discussion. That is, I will look back on the experiences of my Kansas years, using these four domains, in order to better understand my own theoretical orientation.

A word about the title of this essay. Since I cannot deal with everything in such limited space, I would like to orient this autobiographical snippet to explaining why I have never met a theory I didn't like, to say nothing of a metatheory I didn't love.

However, before getting to that, a few words are in order on the issue of honesty. In that recent review essay in Contemporary Sociology I criticized the authors of various autobiographical statements for their false honesty; for their failure to be honest enough. (To show you further what I know, the current editor of Sociological Theory, one Alan Sica (1991), has written a review of one of those books in Science in which he praises the authors for their honesty.). This clearly places a great burden on me to be ruthlessly honest in. this talk. I will try to do that here (I've already confessed to being neither a sociologist nor a sociological theorist), but it is clear that there are at least two limits on being completely honest. First, there are limits to self-insight and I may be deluding myself on a variety of grounds. Second, I do not want to hurt anybody's feelings, especially the feelings of anyone reading this essay. (Hence, I will not tell you about my recollections of Bob Antonio's first years as an Assistant Professor here, or of his credentials to pontificate on the intricacies of such things as Habermasian theory. Let me put it this way, there was little indication in his early essay in NIP (News in Pictures) of the scholar who would ultimately emerge. Recently, I edited a collection of essays (Ritzer 1990a) to which Bob was a contributor. The book included essays by many of the leading theorists in the United States, but it was only in the case of Bob's essay that I had to go to the dictionary, and repeatedly, to look up words. I suppose Bob picked up those terms in the pool halls, ice houses, and pizza 
parlors of New Haven. Enough about Bob, at least for the moment, although I could go on for pages.)

Back to honesty (having just savaged Bob with great probity), I was struck, as I mentioned earlier, by the similarities between Julia Phillips's experiences in Hollywood and mine in Lawrence. The Hollywood stars and their experiences had their parallels in the Kansas sociology department. For example, Warren Beatty is described as "priapic," Paul Newman is spacy, and Margot Kidder is a "sex beast." Although I cannot push honesty to the point of making explicit the Kansas parallels, any of you who were there at that time will know who and what they are. Just kidding (I think).

With all of this as background, let me turn to the four types of MU from a biographical perspective.

\section{INTERNAL-INTELLECTUAL}

The internal-intellectual arena involves a concern for my intellectual training and personality (defects) as well as for the ideas that dominated the Kansas sociology department. We have already touched on the issue of my academic training, or more accurately lack thereof. Suffice it to say that $I$ continued to learn sociological theory during my tenure at Kansas, and persisted in passing on much misinformation to students, although I hope in progressively declining degrees and amounts.

Turning to personality, I need to mention a diagnosis made of my basic personality defect by a former student of mine, currently a professor of sociology at the University of Florida, Hernan Vera. (While we're on former Kansas students of mine, I can't help mentioning perhaps my greatest contribution to contemporary sociology. That is, the fact that I left $\mathrm{KU}$ and Jill Quadagno in the lurch in 1974, which allowed Jill to avoid writing a dissertation on some obscure issue in Weberian theory (sorry Alan Sica), to move on to the far more fruitful domain of gerontology, and ultimately to the Claude and Mildred Pepper Chair in gerontology at Florida State. Had I stayed at Kansas, Jill would probably just now be wrapping up her dissertation on the relationship between Weber's fears of nocturnal emissions (Mitzman 1970) and the rationalization of automobile emissions. Not a bad title- it's not too late, Jill.)

Back to Hernan Vera. Hernan understood how little I knew about sociological theory and spent about a year tutoring me in theory before he could bring himself to ask me to be his advisor. (Hernan is notable also for kneeling unobtrusively in his graduation gown so that I would appear to be taller than he was. There is some bizarre Chilean notion that advisors should both be taller than their students and know more than they do.) Eventually, Hernan came to the conclusion that what defined my personality was what he called "aggressive retreat." Over the years, I have found that to be an increasingly accurate depiction of my personality and it is one that informs my work. For example, in this talk I am aggressively taking the arrogant position of doing an autobiography, but at the same time I am retreating by confessing all (well, not all, not anywhere near all) of my weaknesses. More generally, I have always sought to tackle in an aggressive manner some of the most controversial issues in sociological theory, but then invariably concluded that what was needed was more harmony and integration.

While we're on personality characteristics, there's another one worth mentioning, this one pointed out by my wife during the Kansas years (who, unbelievably, is still my wife). Based on her training as a counselor, Sue argues that as a child of an alcoholic parent, I am unable to handle conflict and that I am forever seeking to reconcile competing perspectives and orientations. There is much truth in this in my work, although it is far less true in my personal and professional relations. Let me deal with the latter point first.

I have always been involved in acrimonious relationships with colleagues. In fact, the reason I came to Kansas in 1970, after only two years at Tulane, was that I had gotten into a battle with a Full Professor in that department (Jeff Hadden) and he had made it clear that as a result my future prospects at Tulane were bleak, to put the absolutely best light on it. Luckily, I had met Chuck Warriner while he was a visiting professor at Cornell and Chuck, Lord knows why, wanted me to come to KU. (By the way, in a letter of reference that he wrote for me, the best thing that Chuck could say about me was that I was "nettlesome." When Ken Kammeyer read this paper for me he claimed that it was he who called me nettlesome in his letter on my behalf to the University of Maryland.) I did move to $\mathrm{KU}$ and I came as an Associate Professor (thank you Jack Baur). No sooner had I arrived at Kansas, but I found myself in the midst of a factionalized department and at odds with the leader of one of the major factions (Dave Willer). (There was even a time when Bob Antonio would not speak to me [something to do with being too rough on poor Bobby on the basketball court], although that did not stop him from continuing to visit my home, fall asleep in front of the fireplace, consume innumerable dinners and huge quantities of ice cream.) Nor, did my combativeness cease when I left Kansas, because early in my tenure at the University of Maryland I almost (so, I'm no Al Gouldner) had a fist fight with David Segal. Things have settled down in recent years, largely because I teach at a commuter campus and I go to campus and see my colleagues on only very rare occasions. As Lewis Coser, and before him Georg Simmel, pointed out-you can't conflict with people if you don't have any contact with them.

In my work, in contrast, it is the case that a consistent theme is conflict and its resolution. In my dissertation, later published as a book (Ritzer and Trice 1969), I was concerned with the ways in which personnel managers resolve role conflict. For many years, I have been interested in the techniques used by workers in various occupations to cope with conflict on the job. This issue has been at the heart of my text in the sociology of occupations (Ritzer and Walczak 1986), the first edition of which was published in the middle of my Kansas years. More importantly, conflict resolution goes to the heart of the work on metatheory that has concerned me for almost two decades. 
It was during my years at Kansas that I wrote, over the objections of Antonio who thought then and still thinks that I was misguided, Sociology: $A$ Multiple Paradigm Science (Ritzer 1975a). On the one hand, that book is comprehensible as part of my continuing effort to understand sociology in general and sociological theory in particular. On the other, it sought not only to lay out sociology's separable, and often conflicting paradigms, but also to make the case for paradigm linking, leaping, bridging, and integrating; in short, for anything but paradigm conflict. Uncomfortable with paradigmatic conflict, I wanted to see more harmony and integration in sociology. That led to the eventual publication of Toward an Integrated Sociological Paradigm (Ritzer 1981) in which I more fully developed my sense of an integrated sociological paradigm. In recent years, the interest in resolving theoretical conflict has led me to focus on micro-macro (Ritzer 1990b) and agencystructure (Ritzer, forthcoming a) integration as well as the larger issue of theoretical syntheses (Ritzer 1990a). As I see it, there is considerable evidence that sociological theory is moving away from decades of theoretical extremism and conflict and toward greater theoretical integration and harmony. But, given my personality, what would you expect me to see? Is this little more than wishful thinking on the part of someone who can't bear conflict, even among remote theories and paradigms?

The whole issue of my interest and concern with metatheoretical concerns is also explicable from the twin points of view of trying to understand theory better and to resolve conflict within sociological theory. In my most recent book, Metatheorizing in Sociology I have, in effect, raised my need to know more about sociological theory to the level of a need for the discipline as a whole. Metatheorizing is, after all, simply the systematic study of sociological theory. I believe that we need to do more of this in order to understand theory better, in order to produce new theory, and in order to produce new overarching theoretical perspectives (or metatheories). In addition, such metatheoretical study is also oriented to clarifying contentious issues, resolving disputes and allowing for greater integration and synthesis. Another attraction of metatheoretical work, from this point of view, is that it is so remote from the "real world" that the conflict I find there is relatively painless and easy to cope with.

Turning from psychology to physiology, the fact that I am short in stature has led me to want to grapple with only big questions. This is related to another major personality disorder--an impatience for minutia and a resulting concern with the bigger picture. For me, empirical research, now but a dim memory, seemed too much like Kuhnian puzzle solving. I wanted to deal with the puzzle in its entirety rather than trying to add one tiny piece to the ultimate solution. Hence, metatheory which permits me to survey the entire range of sociological theory. Recently, one of the issues that I have been working on is the relationship between metatheory and metamethods and meta-data-analysis. This permits to move beyond theory and to deal also with the study of methods and data analytic techniques. (Of course, I know nothing about the latter issues, but such ignorance never impeded me in theory so I see no reason why it should be a problem in those areas.)

\section{INTERNAL-SOCIAL}

The internal-social domain leads to a concern for such things as the social atmosphere and social relationships in the Kansas sociology department. The department was then, as it was before, and as it has been since, a remarkable place. Indeed, it is hard to explain how the state of Kansas has been able to sustain such a consistently strong sociology department. God knows it is not as a result of the state's largesse and the astronomical salaries paid to faculty members.

But the fact is that during the years that I was at Kansas, 1970-1974, this was a notable department, especially in sociological theory. Chuck Warriner, Dave Willer, the much-maligned (by me) Bob Antonio, and I were all focally interested in theory and this represented a significant proportion of the entire department. Beyond the substantial strength at the faculty level, was an even greater concentration of interest in theory among graduate students like Quadagno and Vera, as well as others such as Richard Bell and Doug Heckathorn. The result was a swirl of activity in theory and an environment conducive to working on theory.

I have never been able to approximate the intellectual atmosphere that existed in my seminars at Kansas, especially those held at my home and that involved almost as much consumption of wine and food as theoretical ideas. It was not unusual for my living room to be packed with students (and Bob Antonio who thought of himself then, and come to think of it, still thinks of himself, as a student), with the overflow sitting on the stairs leading to the second floor. Discussion often went on well into the night and not a few participants left staggering under the weight of a welter of theoretical ideas and too much wine. (To this day, David Quadagno doesn't believe that Jill's late nights under the influence had anything to do with sociological theory.) Such seminars could have only taken place in a small college town and before our consciousness on such matters was raised by such organizations as MADD.

\section{EXTERNAL-SOCIAL}

Beyond the atmosphere in and around the sociology department was the atmosphere at The University of Kansas. These were still the heady days of the anti-war and student movements. The campus was alive with activity and with ideas. It was an environment that helped foster intellectual creativity. And, of course, beyond the campus was the broader arena of social activity and intellectual ferment that characterized the early $70^{\prime}$ s. It was an exciting and stimulating time to come of age as a scholar. Now, if only I had come of age, if only I had been a scholar. 


\section{EXTERNAL-INTELLECTUAL}

Finally, a concern for external-intellectual issues would lead to an interest in the ideas that dominated sociology of the day as well as the ideas derived from other fields (for example, Thomas Kuhn's philosophy of science). My arrival at Kansas in 1970 coincided with the demise of the hegemony of structural functionalism, the rapid growth in interest in Marx's ideas and neoMarxian theories of various types, and the emergence of such micro-theories as ethnomethodology. The theoretical landscape was changing and I desperately needed to make sense of it, if for no other reason than to be able to explain it to my students. My effort to try to understand this landscape was aided, I believe, by the fact that I had not been trained in sociological theory. I had not been trained in a particular "school;" I was the supporter of no particular "school of thought." As a result, I came to the study of sociological theory with few prior conceptions and biases. I was not a structural functionalist, a conflict theorist, a symbolic interactionist, or an exchange theorist. Rather, I was a student of all of them; they were all equal grist for my theoretical mill. Hence, the reason for the fact that I never met a theory I didn't like. It was not a question of like or dislike, but rather all of the theories were (and are) my data.

Thus, to give one example of the theoretical mill in which I was grinding theories, I was perplexed from the beginning by the accepted wisdom of the day (and probably to this day, despite my best efforts to point out its fallacies) that the major split in sociological theory was between conflict theory and structural functionalism. As I saw it, both of these theories had much more in common than they had differences. They shared an interest in social structures and institutions and their coercive effect on individuals. They differed in whether or not structures were in conflict with one another and whether or not people were coerced or accepted their constraint. While these are important differences, they pale in comparison to the differences between these two theories and other theories like symbolic interactionism, ethnomethodology, phenomenology, and exchange theory.

This, in turn, led to a view that structural functionalism and conflict theory had "something" in common and whatever it is that they shared differed from what the other theories had. What that "something" turned out to be was a paradigm in Thomas Kuhn's sense of the term; structural functionalism and conflict theory shared a paradigm, what I came to call the social facts paradigm because of its focal concern with Durkheimian, macro-level social facts. The other theories turned out to be part of other, very different paradigms--the social definition and social behavior paradigms. Hence the view that sociology was a multiple paradigm science.

While it would be nice to be able to say that I set out to analyze the state of sociological theory using Kuhnian concepts, the reality was quite different. Early in my tenure at Kansas, Norm Yetman had introduced me to the editor at Allyn and Bacon and that led, in 1972, to the publication of an anthology, Issues, Debates and Controversies (Ritzer 1972) in which I sought, quite characteristically, to continue my efforts to learn some sociology (and earn some fame and money in the process) by reviewing some of the major intellectual conflicts in sociology and the efforts to resolve those conflicts. The success of that book (in terms of sales) led to the idea that I try to do a Peter Berger type invitation to sociology. I wrote a draft of the book which outlined three broad sociological approaches, but one of the reviewers commented that it really cried out for a Kuhnian type analysis (Norm Yetman recalls that he pointed me in the direction of Kuhn's work). Of course, at that point I had not read, or even heard about, Thomas Kuhn. The reading of Kuhn led me to a better sense of theory, to paradigms, to an integrated sociological paradigm, and ultimately to metatheorizing in general.

The mention of Norm Yetman's role in my now two-decade long association with Allyn and Bacon, reminds me of some of the most satisfying times at the University of Kansas. While you might think they were long, deep discussions about the intricacies of semiotics, the fact is that they took place on the basketball court. My height, or rather lack of much of it, not only affected my intellectual work, but it drove me to succeed on the basketball court. Since I was unlikely to do much damage amid the "trees" near the basket, I perfected my ability to shoot from anywhere from 20 to 30 feet. (I'm tempted to say 40 feet, but readers of this essay may have been there.) In addition to taking long shots, I also took them often...very often...and with some accuracy. Indeed, I still glow when Norm tells colleagues at professional meetings how I was the best pure shooter he ever saw.

Now, Norm and I played well together, in part because he couldn't shoot at all. But what Norm could do was to injure the opposition. Not that Norm ever intended to hurt anyone, but he was (and is...I guess) big, strong... and possessing absolutely no control over his body. Once in motion, that hulk (or is it hunk?) tended to hurtle in this direction and that and bodies were apt to be strewn across the floor. Having levelled the opposition, Norm, ever the Minister's son, would pass up a shot for himself, throw the ball back to me, and I would accommodate Norms's need for sainthood by shooting from thirty feet. The two of us often played with Stan Eitzen who could also shoot the basketball. The three of us loved to go to the gym looking like two balding, middle-aged men and their youthful, Adonis-like friend and challenge some undergraduates to a game. They invariably took us for granted and we invariably won. Invariable, also, was the fact that one of the opposition would end up bloodied by one of Yetman's errant appendages hurtling through the air.

I have to mention Bob here or else he'll be offended since much of his sense of self revolves around his "abilities" as a basketball player. Bob did play basketball, at least I think that's what he played. Bob was willing and eager on the court, as he is in the classroom and in his professional activities, but he didn't have what one would call a soft touch. In fact, when he shot the ball, it was not unusual for the (steel) backboard to buckle. When Bob played against me, he invariably tried to use his huge height advantage (Bob must be $\left.5^{\prime} 7^{\prime \prime}\right)$ by playing near the basket. In response, I was forced to foul him 


\section{Mid-American Review of Sociology}

unmercifully. It was as a result of one particularly brutal assault that Bob, as I mentioned before, stopped speaking to me.

Then there was Bob and the chicken pox. I contracted chicken pox one vacation and by the time I returned to Lawrence I was covered with lesions. As you may know, Bob is a hypochondriac, I mean a big-time hypochondriac (he often projects his hypochondria on me), and he wouldn't even phone me out of fear of getting the disease. Finally, after everyone else in the entire city had come to see me, Bob could stay away no longer. I will never forget Bob's expression when he stood by my bedroom door (he could not bring himself to enter the room) and saw what I looked like. His face reminded me of one of Bob's favorite stories about how the Italians were defeated by the Ethiopians in World War II when they learned that the Ethiopians castrated those they captured. Bob looked like he was about to be castrated and fled my room at about the same speed that his brethren fled Ethiopia.

One other anecdote from my Kansas years. One summer Norm Yetman decided to build a concrete patio and asked me to help. I arrived at the appointed morning in shorts and sandals and with a dozen donuts. Waiting for me was a huge truck dispensing its concrete. Norm asked me to push a wheelbarrow full of newly dispensed, wet concrete. Now, I was a New York City kid and I had only seen wheelbarrows in the movies. I lifted the handles and managed to take one step before the wheelbarrow tipped spilling concrete all over Norms's lawn. How was I to know that a wheelbarrow had only one wheel? From that point on, I was put in charge of refreshments for those helping Norm with his patio.

But I digress, but then again digression is a major aspect of this paper. I completed Multiple Paradigm Science in 1974 and about that time, my good friend then, and now, Ken Kammeyer (Ken is so gentle that even at my most nettlesome, he never conflicts with me) was interviewing for the chairmanship at the University of Maryland. For some reason, Sue and I had decided we wanted to go back East and Ken, with some coaxing, decided to take me with him. The early years at Maryland were hard and we often regretted having. left Lawrence. We have never come close to creating the kind of intellectual and personal community we had during our Kansas years.

The intellectual agenda that I began at The University of Kansas has continued to inform my work to this day. As mentioned previously, the book on multiple paradigms led to ideas on an integrated paradigm, to essays on micro-macro and agency-structure integration as well as on the movement toward theoretical syntheses as we move into the $1990 \mathrm{~s}$, and ultimately to metatheorizing in general. There is considerable interest in metatheoretical work these days and I feel good about playing a role in sparking some interest in this very distinctive kind of sociology.

I also initiated another long-term set of interests during my tenure at Kansas. I wrote a paper on Weber's theory of rationalization and its relationship to professionalization (Ritzer 1975b). I have been mining Weber's rationalization theory ever since. I wrote a paper on McDonaldization (Ritzer 1983) in which I argued that while the bureaucracy was the paradigm case of
I Never Metatheory I Didn't Like

formal rationalization in Weber's day, in modern society that model is the fast-food restaurant. I have recently come back to that issue and a book fast-food restaurant it he Big Mac Attack: The Moldization of Society dealing with that theme, Big Mac ablished shortly. I have also continued to (Ritzer forthcoming b), will be published shortly. write on the relationship between rationalization and the profs seading to the most recently, that the increase in formal rationalization is leading One of my deprofessionalization of medicine (Ritzer and Walczak 1988). One with the ongoing projects (wich automobile industry and the success of its Japanese failure of the Am thesis is that the American failure is traceable to its exclusive reliance on formal rationality while the Japanese success is linked to its reliance on form involving the utilization of all four Wet

hyperrationality involving the untellectual, and practical. Thus, in a very real sense I have merely played out and extended an intellectual agenda that was set, undoubtedly largely unknowingly, during my four years at Kansas.

I have been reflecting on what my life would have been like had I, like many others, never left Kansas. A few guesses:

1-While I might be poorer economically, I would be much richer interpersonally. I have developed few new friendships since I left Kansas. The ones I had at Kansas would undoubtedly now be much richer and deeper.

2-My work would be much better. Always inclined to be a loner, the

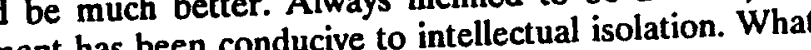
I have dene largely on my own. Had I stayed at Kansas, my I have done, I have done largel by what I would have learned from the work would have been enriched by what $I$ would with the department.

long line of theorists who have been associated with the departme

3-I would have been made miserable by the political infighting that has characterized the Kansas department. Maryland has no community so we neither commune nor conflict with one another. Given

conflict, Maryland was clearly the better place for me.

Yet Kansas is a place of strong emotion and identity for me. While I am lad I did not suffer the trials and the tribulations of the last two decades at gan that I passed through the department. It left an also glad that ins pas my personal life...as well as a scar on my nose from the chicken pox.

\section{REFERENCES}

Mitman, Arthur. 1970. The Iron Cage. New York: Universal Library. The Iron Cain. New York: Random House. 
Mid-American Review of Sociology Ritzer, George. 1975a. Sociology: A Multiple Paradigm Science. Boston: Allyn
and Bacon.

1975b. "Professionalization, Bureaucratization and Rationalization:

The Views of Max Weber." Social Forces June:627-634.

1981. Toward an Integrated Sociological Paradigm: The Search for an 1983 "The Image of the Subject Matter. Boston: Allyn and Bacon.

6:100-107.

Delineation "Sociological Metatheory: A Defense of a Subfield by a 1990a. "The Parameters." Sociological Theory 6:187-200.

Syntheses." Pp 1-30 in Frontiers of Sociological Theory: The New

edited by George Ritzer. NY: Cof Social Theory: The New Syntheses, 19906 Mrge Ritzer. NY: Columbia University Press.

Metatheoretical Tool." Pp. 347-370 in Frontiors of Sheory: Applying a

Syntheses, edited by Geors 1991a. Metatheorizing in Ritzer. NY: Columbia University Press.

1991b. "Biography: A in Sociology. Lexington, MA: Lexington Books. Contemporary Sociology 20:10-12.

- Forthcoming a. "Agency-Structure and Micro-Macro Linkages: Agency, edited by Bjorn Wittrock Agency, edited by Bjorn Wittrock.

. Forthcoming b. The McDonaldization of Society. Lexington, MA:

Ritzer, George (ed.). 1972. Issues, Debates and Controversies: An Introduction to Sociology. Boston: Allyn and Bacon.

1990a. Frontiers of Sociology: The New Syntheses. New York: Columbia University Press.

Ritzer, George and Harrison Trice, 1969. An Occupation in Conftict $A$ Sudy of the Personnel Manager. Ithaca, NY. Coccupation in Conflict: A Study

Ritzer, George and David Waltaca, NY: Cornell University. edition. Englewood Cliffs NJ. Prenti Working: Conflict and Change. 3rd ion. Englewood Cliffs, NJ: Prentice-Hall.

. 1988. "Rationalization and the Deprofessionalization of Physicians." Social Forces 67:1-22.

Sica, Alan. 1991. Review of Bennett Berger, ed Authors of Their Own Lives. Science January 18, 1991, 251, 4991:324.

\section{META-SOCIOLOGY: DOINGS AND REFLECTIONS}

\author{
W. Richard Scott
}

Stanford University

Mid-American Review of Sociology, 1991, Vol XV, No. 2:33-42

It's a pleasure to be here. In listening to the previous speakers, it's clear that $\mathrm{KU}$ is a special place that evokes fond memories from those of us who have had any connection with her. I am delighted to be a part of this celebration; and I am honored to be among those whom you have asked to return and to participate.

I have called my remarks "Meta-Sociology: Doings and Reflections." Like many of you, I am not quite sure what "meta" means, but, knowing that George Ritzer was going to address a related theme, I was depending on him to give you the in-depth interpretation. I will settle for the shallow view. I think I got my first sense of this concept from watching the Gary Shandling Show. You recall how Gary often goes off the TV set and watches the other characters on the TV monitor to find out what they are saying and in the scenes in which he is not involved. To make a "meta" approach is to step out of doing the usual kinds of things we do--the teaching, the research, the advising--and, instead, to reflect on what we are doing: to attempt to make sense of what we are up to when we teach, inquire, advise, and so on. So I am here not to talk about my research but about why I decided to do the research that I did; I am here not to present my work but to talk about what working means to me; I am here not to do sociology, but to talk about doing sociology.

Before I begin to engage in such talk, three quick comments on this type of enterprise. First, the exercise is enticing. There is something fascinating about self-reflection. I think we are all intrigued by biographies--especially our own. When Alan Sica invited me to talk about the development of my own career, my first reaction was disbelief; my second, anxiety; and my third, attraction. I began to feel more and more like Gilbert and Sullivan's elderly Duchess, "who doesn't think she dances, but would rather like to try."

Second, I must point out that the exercise, if performed en masse, could be harmful to the field. The danger is well described in Carl Sandburg's poem, "The People, Yes," in which everyone agreed on a given signal to shout so as to be heard by the heavens; but when the moment came, there was complete silence because everyone wanted to hear the wonderful noise. In short, if we all become too self-reflective, there will be no one to do the work.

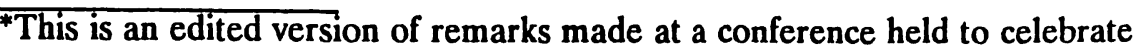
the centennial of the founding of the Department of Sociology at the University of Kansas, Lawrence, Kansas, on April 5-6, 1991. 